University of Wyoming College of Law

Law Archive of Wyoming Scholarship

7-25-2013

\title{
Wilhelm Kroll's Preface to Justinian's Novels: An English Translation
}

David J.D. Miller

University of Bristol, dandi.miller@blueyonder.co.uk

Timothy G. G. Kearley

University of Wyoming - University of Wyoming, College of Law, tkearley@uwyo.edu

Follow this and additional works at: https://scholarship.law.uwyo.edu/faculty_articles

\section{Recommended Citation}

Miller, David J.D. and Kearley, Timothy G. G., "Wilhelm Kroll's Preface to Justinian's Novels: An English Translation" (2013). Faculty Articles. 9.

https://scholarship.law.uwyo.edu/faculty_articles/9

This Article is brought to you for free and open access by the UW College of Law Faculty Scholarship at Law Archive of Wyoming Scholarship. It has been accepted for inclusion in Faculty Articles by an authorized administrator of Law Archive of Wyoming Scholarship. 


\title{
Wilhelm Kroll's Preface to Justinian's Novels: An English Translation David J.D. Miller and Timothy Kearley
}

\author{
Introduction \\ Timothy Kearley
}

The emperor Justinian's legislation continues to be relevant for historians of the law. As Caroline Humfress has written:

For the legal historian, the Age of Justinian is nothing short of pivotal. Medievalists and early modernists interested in the so-called reception of Roman law in later times and places must look back to Justinian and his law books, as classicists and historians interested in Roman republican or early imperial law must frequently look forward to them. ${ }^{1}$

Justinian's law books are, of course, the Digest, the Code, the Institutes, and the Novels (Novellae Constitutiones), which have become known collectively as the Corpus Iuris Civilis (CIC). ${ }^{2}$

It soon becomes clear to those interested in the $\mathrm{CIC}$ that the standard modern version is based on the works first created in the late $19^{\text {th }}$ century by Theodor Mommsen (Digest-Berlin, 1870), Paul Krüger (Institutes-Berlin 1867, and Code-Berlin 1877), and Rudolf Schoell and Wilhelm Kroll (Novels-Berlin 1895). These were formed into a three volume, stereotype set early in the $20^{\text {th }}$ century. ${ }^{3}$ Wolfgang Kunkel has noted: "By comparison with this stereotype edition (which offers the same text in all editions), older general editions of the Corpus iuris can be used only as auxiliary material." 4

However, Mommsen, Krüger, Schoell, and Kroll offer more than the best-regarded versions of Justinian's legislation. Their prefaces to the Digest, Code, and Novels describe, among other things: the many manuscripts they read and used in their recensions; their criteria for accepting some readings and rejecting others; the previous printed editions and their flaws. Moreover, while there is an English translation of Mommsen's Digest, ${ }^{5}$ and although English translations are planned for

${ }^{1}$ Caroline Humfress, Law and Legal Practice in the Age of Justinian in THE CAMBridge Companion To The Age of Justinian 161, 162 (Michael Maas ed., 2005).

2 The title Corpus Iuris Civilis was first applied to a printed collection of the Justinian texts by Dionysius Gothofredus in 1583. See A. ARTHUR SCHILLER, RomAn LAW:

MECHANISMS OF DEVELOPMENT $§ 12$ at 29-30 (1978).

${ }^{3}$ Vol. 1, Institutes and Digest (1911); vol. 2, Code (1915); vol. 3, Novels (1912).

There have been many subsequent editions and reprintings of this set.

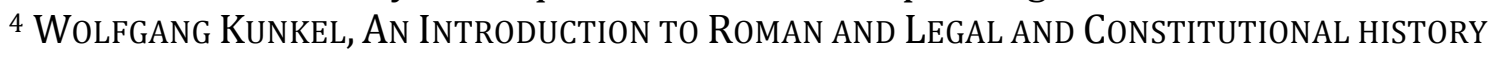
223 (J.M. Kelly trans., $2^{\text {nd }}$ ed. 1973).

5 The Digest of Justinian (Theodor Mommsen, Paul Krüger \& Alan Watson eds., 1985). 
the Code ${ }^{6}$ and the Novels, ${ }^{7}$ the first does not include a translation of its preface, and none is planned for the prefaces of the latter two. Neither did Justice Fred H. Blume, whose translations of the Code and the Novels I edited and published on the web, translate the preface of either work. ${ }^{8}$

It is true that much of the information contained in Kroll's preface to the Novels can be pieced together from scattered sources in languages more accessible than Latin. For example, Krüger's German monograph on the history of the sources and literature of Roman law covers the Novels in some detail; ${ }^{9}$ Noailles described the Novels extensively in French; ${ }^{10}$ and I have written at length in English of the Novels and their transmission. ${ }^{11}$ However, Kroll's Preface contains unique detail and insights in a relatively compact form, and it has remained inaccessible to all but those who can comfortably read Latin-an ever-decreasing percentage of the population. Therefore, this selective translation of Kroll's Preface will perform a useful function.

I began this translation simply as an effort to have first-hand knowledge of information I had seen referred to in the course of my research on Justinian's Novellae Constitutiones. I had read much about the Novels, but I thought there probably was a good deal of interesting and valuable information in Kroll's Latin preface to his and Schoell's recension that was missing from the other sources.

So, I translated the Praefatio as part of the laborious (and ongoing) process of teaching myself Latin. After years of working half an hour here, forty minutes there, I finished. But many passages remained mysterious, and I knew that, aside from those parts, the translation as a whole would amuse anyone who really understood Latin and might mislead anyone who didn't.

Meanwhile, I had developed a cordial email correspondence with David J.D. Miller, who along with Peter Sarris, is creating a new translation of the Novels for the

${ }^{6}$ An edition by a team of translators led by Bruce Freer of the University of Michigan is due to be published by the Cambridge University Press in 2014.

${ }^{7}$ By David J.D. Miller and Peter Sarris, also to be published by the Cambridge University Press.

8 Fred H. Blume, The Annotated Justinian Code (Timothy Kearley ed., $2^{\text {nd }}$ ed. 2010), http://www.uwyo.edu/lawlib/blume-justinian.

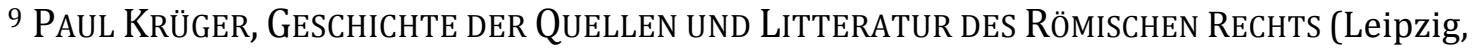
Duncker \& Humblot 1888), available at http://archive.org/details/geschichtederque00kr; see also FRIEDRICH AUGUST BIENER, GESCHICHTE DER NOVELLEN JUSTINIAN'S (Berlin, Dümmer 1824), available at http://books.google.com.

10 PierRe NoAilles, Les Collections de Novelles de L’EmPereur Justinian (1912-1914), available at http://openlibrary.org.

11 Timothy Kearley, The Creation and Transmission of Justinian's Novels 102 LAW LiBR. J. 377 (2010), available at http://www.uwyo.edu/lawlib/blumejustinian/_files/docs/ajcnovels2/novelsart._llj_ed.pdf. 
Cambridge University Press from the Greek and was finding useful Justice Blume's annotations and translation (from the Latin). When I mentioned my English translation of the Preface, the Latin (and Greek) teacher in Miller overcame his better judgment, and he volunteered to review it and make corrections. This inevitably became a wholesale revision inasmuch as my original was vastly deficient (perhaps not as risible as the infamous English AS SHE IS SPOKE by Pedro Carolino and José da Fonseca, but occasionally having that flavor). (Available at http://www.gutenberg.org/ebooks/30411)

So, it is fair to say, using Hollywood terminology, that this translation is "by David J.D. Miller, based on an idea by Timothy Kearley," though I am not trying to escape responsibility for any errors into which I may have led Miller. I am extremely grateful to latter for saving me from embarrassment, for putting this Preface into readable, accurate English, and for teaching me a great deal.

As noted above, this is a selective translation. In order to provide a sense of the task Schoell and Kroll faced, we translated some of Kroll's detailed discussion of manuscripts and variant readings. However, we omitted other similar descriptions as being tedious for the vast majority of readers. Our translation is based on the Praefatio in the 1912 edition, that being the last Kroll corrected. Because this is available to the reader electronically at http://books.google.com, we have included only limited explanations of the abbreviations Kroll uses in his narrative. For example, at his first mention of $\mathrm{M}$, we explain in a footnote that this is the crucial Codex Marcianus Graecus; however, we leave it to the reader to refer to the Signorum Explicato page following the Praefato to find that Neob. refers to the Codex Claustro-Neoburgensis 62.

Also owing to the ready availability of the electronic edition, we have included boldfaced page and column numbers in brackets for those who might want to find the corresponding Latin text in the Praefatio; e.g. [IV.1] precedes the text of our translation that corresponds to the Latin in the first column of page IV in the original. These markers also are important because Kroll numbered his footnotes independently for each column; hence there sometimes are two footnotes 1 or 2 on the same page, and the reader of our non-columned format will need to use the bracketed page and column numbers to identify the proper footnote. We used lower case letters for our own footnotes.

We hope the reader will find interesting and useful the insights provided by one of the editors of this classic work of scholarship. 


\section{Justinian's Novels, Preface Wilhelm Kroll \\ Translated by David J.D. Miller and Timothy Kearley}

[III.1] When Rudolf Schoell was taken away from us by premature death, he left an unfinished edition of Justinian's Novels, which he had hoped to complete before the end of the year 1893. Thus, Theodore Mommsen, looking around for someone who could bring it to completion within approximately the same time span, at last by accident came upon me, who, not without some hesitation, undertook the work, and perhaps would have declined it if I had then known all the difficulties involved. I hope, at least, that those who will be passing judgment on my labors, as well as his, will consider how foreign this field is to a scholar accustomed to very different subjects.

But to avoid a circuitous route and come to the main point, at the time of Schoell's death Novels 1-134, c. 13, p. 688 (fasc. X-XIV; vol. III, fasc. I-IV) had been set in type; the following all the way to Novel 163, p. $750,18^{1}$ were so very nearly completed they could be put into type; beyond this were present a few quite isolated sheets of paper regarding the five last novels; a scanty notes to the edicts; and neither hide nor hair of aids towards editing the appendices. Thus, the principle I used for myself was to keep whatever I thought Schoell would have kept; where he showed that he had not reached a positive decision, I followed my own insight to the best of my ability; if errors were discovered, they were silently removed. It is quite unclear what kind of Preface he was going to compose, and he certainly left no studies at all towards tracing the history of the text; so I hope for forgiveness on both counts, in taking it as sufficient to list the aids used for this edition. ${ }^{2}$

\footnotetext{
${ }^{1}$ Henceforth, first person statements (correxi etc.) were not made by Schoell. I have not used the asterisk by which it was his custom to mark emendations of his own. a We have used a lower case " $n$ " when Kroll seems to refer to an unspecified individual law or laws and an upper case "N" when he refers to a specific law or laws and to them as a collected work.

${ }^{2}$ Cf F.A. Biener, Geschichte d. Novellen Justinians (Berlin 1824); Zachariae von Lingenthal, Geschichte d. griechish-römischen Rechts ( ${ }^{\text {rd }}$ ed. Berlin 1892); P. Krueger, Geschichte d. Quellen und Litt. d. röm. Rechts (Leipzig 1888) p, 355 ff.
} 
So then, Justinian's Novels [III.2] [Greek] a (new constitutions since the Code) existed in several forms in the past, whereof the three better known to us are:

I. The Collection of 168 Novels

II. That used by the old Latin translator (the Authenticum)

III. That from which Julian's Epitome is derived.

The Collection of 168 Novels was constructed in Constantinople during the reign of Tiberius and rests upon an older collection of Justinian novels containing just those enacted up to the year 544, to which are annexed more recent laws of the same emperor, and also four of Justin $(140,144,148,149)$, three of Tiberius $(161$, $163,164)$, and three edicts of praetorian prefects (166-168). It also contained those laws which had been drawn up in Latin, and had no Greek versions appended. ${ }^{\mathrm{b}}$ No manuscript displays this collection complete (though $\mathrm{M}$ has it nearly complete) c; but by application of every resource, we are enabled to restore it to an almost complete state, more or less such as you see in this edition.

From this same corpus was derived the epitome created by the law-official Theodorus of Hermopolis, who also composed a summary of the Code in Greek; it seems to date shortly after the year 575 . In one manuscript, it bears the inscription: [Greek] Summary of the new constitutions, with references to the corresponding section either of the Code or of the Novels themselves; by the law-official Theodorus of Hermopolis in the Thebaid. His arrangement was for the number, heading and preface to be followed by an epitome, to each head of which are subjoined references, i.e., mentions of places in the Code, or in the Novels themselves, that are perceived as relevant to the understanding or illustration of the constitutions;

\footnotetext{
a Italics preceded by [Greek] denote Greek text translated into English. Italics also are used for Greek or Latin words not translated into English. Words in brackets are those of the translators.

b That is, not in that particular Latin collection. ${ }^{\mathrm{c}} \mathrm{M}$ is the designation used by Kroll and Schoell (and others) for the $13^{\text {th }}$ century manuscript known as the Codex Marcianus Graecus 179 and also as the Codex Venetus, because it was housed in the library at St. Mark's in Venice. It previously was in Cardinal Bessarion's library. Timothy Kearley, The Creation and Transmission of Justinian's Novels 102 Law Libr. J. 377, ๆ29 at 338 (2010).
} 
subscriptions ${ }^{a}$ are always attached. It was edited from the palmary manuscript Athos 37, of the 11th century, which ceases at Nov. 166's words [Greek] ...of the times... ${ }^{b}$ by Zachariae, Anekdota (Leipzig 1843, p. 1-165).

[IV.1] The Corpus of the 168 Novels was used by those who, by order of Leo (869911) compiled the Basilica. How many and which novels they included we discern from the scholion from Tipucitus' silken (?) [? follows bombycino in original] MS Vaticanus 853 of the $14^{\text {th }}$ century, f. 500 r, where it is at the end of book 60 of the Basilica. It was first published by Alemannus [1623] in his notes to Procopius' Secret History, XIV, p. 8; thereafter, by Heimbach, in his edition of Basilica II, p. VIII; [Greek] One must know that 168 novels were composed by Justinian. 141 of these were incorporated at the appropriate sections of the 60 books of the Basilica; the remaining 27 were unmentioned, namely 2. 5. 6, 7, 9, 11, 40, 46, 50, 54, 55, 56, 58, 74, 75, 76, 79, 83, 84, 98, 106, 127, 129, 137, 140, and 149 (cf. Biener, 135). The scholion is very ancient, or, at least relates to a very ancient MS; for the fact that in the following years a steadily increasing number of novels were omitted in the MSS of the Basilica is testified to by Michael Psellus in [Greek] Concise Analysis of the Novels of Justinian (edited by Heimbach, Anekdota II, Leipzig 1840 p. 243) and the so-called Index Reginae ${ }^{c}$ which says that it tallies 168 novels, adding whether they are now absent in the Basilica, or where in it they are found. These, then, quite agree on those that the scholiast says are missing (except that Psellus is silent on 9 and 10 in Latin and on 54, 55, and 149, and the Index Reginae on 9), but they both say that several more are omitted as to some of which they agree, and some of which they differ. For Psellus and the Index add novels 38, 62 (Lat.), 67, 77, 101, 104 (Lat.), 105, 127, 139, 141, and 154; Psellus alone 161, (but I think 163 should be restored

a I.e. place and date of promulgation, found at the end of each Novel.

$\mathrm{b}$ The Greek words cited come halfway through the summary of the Preface. ${ }^{c}$ A list of rubrics of the 168 Novels first printed in Latin by Cujas, or Cujacius, in 1570. The original Greek text is given in volume 2 of Heimbach's Anekdota. The title stems from its discovery in the queen's library in Paris. See, John Thomas Graves, "The Legislation of Justinian," in 2 Dictionary of Greek and Roman Biography and Mythology 666, 673 (William Smith ed. 1854) available at http://www.ancientlibrary.com/smith-bio. 
for 161), the Index alone 10, 19, 133 (Lat.), 34 (Lat.), 45 (wrongly), 65 (Lat.), 70, 110, 138 (Lat.) 147, 148, 163 (?) [? in original]. Even more are absent from the surviving MSS of the Basilica. ${ }^{1}$ Furthermore, those that were included mostly did not remain intact; in fact, editors of the Basilica certainly always omitted the epilogues with the subscriptions, often the headings, inscriptions, ${ }^{a}$ and the prefaces (scholia to the Basilica did sometimes give the prefaces, less often the inscriptions, and occasionally Theodorus' summaries of whole novels), and besides, the portions of the constitutions themselves that seemed to them less necessary. They included Theodorus' summaries of the Latin ones $(23,35,36,37,62,75,104,111,114,138$, 143 , and 150) and also of a few Greek ones $(51,121,122$ (?) [? in original] and $165) .^{2}$

[IV.2] The 60 books of the Basilica that existed in the past have not all been preserved; certainly absent are 19, 31-37, $43 \& 44,53-59$. But we generally learn which novels were contained in these from the Index Reginae, from those contained in the Coislin and Paris MSS, and from the paratitles of Tipucitus; ${ }^{1}$ in part also from the alphabetical synopsis, and in part from the Ambrosian MS. Thus in B [Basilica]:

\footnotetext{
${ }^{1}$ It is also certain from other sources that there were already abridged MSS extant in the $11^{\text {th }}$ and $12^{\text {th }}$ century; Heimbach VI, p. 158. Hence it can be inferred, from the fact that the novels mentioned by the scholiast, but no others apart from a few Latin ones, are also omitted in MS L [MS L=Codex Laurentianus plut. LXXX 4, 14 th $^{\text {th }}$ century (preface X), sometimes called the Codex Florentinus, because it was housed in the Laurentian library in Florence. See Kearley, supra note $\mathrm{c}$ at 5] that the selection of novels extant in that MS is not much later than the Basilica.

a I.e. the emperor's name and title(s), and those of the addressee.

${ }^{2}$ By the following example, I establish that later copyists relaced complete wording, which had originally been included, by summaries: Nov. 17 is in B. 6.3.22-38, but in MS Paris 1352, there is nothing but summaries of some chapters. Justinian's wording suffered very little damage in $B$, except that Latin words were changed into Greek; but, both here and elsewhere, it must be borne in mind that there is as yet no accurate recension of the Basilica.

1 The paratitles of books 1-12 were edited by Heimbach, II 753, from Vatican MS 853, very badly, as usual (cf. Brandileone, Bulletino dell' Instituto di Diritto Romano $1107 \mathrm{ff}$.); he recorded certain of the subsequent paratitles in his notes to the lists which I have mentioned above. The name of Tipucitus is fashioned from ti pou keitai, Greek for "What has been put where?", cf. Heimbach II p. VII ff. Anekd. I $220 \mathrm{f}$.
} 
Bk. 31 t. 5, 1: Nov. 81 t. 7: Nov. 1027

Bk. 32 t. 1: Nov. 12 4. 1811

Bk. 32 t. 2: Nov. 899

Bk. 32 t. 2: Nov. 1531

Bk. 35 t. 11, 81: Nov. 108 t. 18,1: Nov. 158 t. 20, 2: Nov. 107

Bk. 36 t. 1, 7: Nov. 159

Bk. 37 t. 11, 1-4: Nov. 72 t. 12, 1: Nov. 94 t.12, 2: Nov. 155

Bk. 48 t. 26: Nov. 156

Bk. 55 t. 14, 1: Nov. 157 t. 14, 4: Nov. 122 t. 14, 5: Nov. 156

Bk. 57 t. 5: Nov. 130 t. 8: Nov. 116 t. 9: Nov. 85 t. 19, 1: Nov. 152

Bk. 59 t. 4, 1: Nov. 43 t. 4, 2: Nov. 59

On the others that are now absent from their original locations, Biener, 583 proposes conjectures (cf. Heimbach VI 416 ff.). Cf. infra p. XIV.

Two editions of the Basilica exist, of which one was undertaken by Annibal Fabrot, Paris 1641-1647, encompassing 7 volumes. The following are the books he published, and the MSS he used:

Bks. 1-18, 2, 16 from the Paris codex 1352 parchment $13^{\text {th }}$ century, which has an abridged text

Bks. 20-20 from the MS Paris 1348, silk, $13^{\text {th }}$ century

Bks. 28, 29 from the MS Paris 1354, paper, AD 1556 (copy of the Laurentian MS 80, 11)

Bks. 38-42 from the MS Paris 1349, parchment, $11^{\text {th }}$ century, \& 1354

Bk. 60 from the MS Paris 1350, parchment, 12 ${ }^{\text {th }}$ century.

Reitz provided a supplement (Leiden 1765); he published Bk. 8 from the Leiden codex derived from the now-lost Escorialensis, and Bks. 49-52 from the MS Paris 1357 , paper, $15^{\text {th }}$ century.

The second edition produced by G.E. Heimbach [V.1] (6 vols. Leipzig 188370) made use of the following resources, apart from the publications of Fabrot and Reitz: 
for Bks. 1-9: Coislin. MS 151, silk, $14^{\text {th }}$ century (not $11^{\text {th }}$ century) ${ }^{1}$

for Bks. 11-14: Coislin. MS 152, parchment, $13^{\text {th }}$ or $14^{\text {th }}$ century

for Bks. 28 \& 29: Laurentian, MS 80, 11, parchment, $12^{\text {th }}$ century.

Finally, there has recently been discovered in the Ambrosian Library the MS F106 sup, a palimpsest, the first writing on which is assigned by experts to the $10^{\text {th }}$ century. It exhibits excerpts from the whole work of the Basilica (Ba). Ferrini and Mercati have published what they were able to read in the MS Leipzig 1897 (=vol. VII of the edition of Heimbach). I have collated the passages in the novels that they read with our edition, and have noted the following variant readings: [there follows a lengthy list of the Greek variant readings in each of the six novels found (in part) by Ferrini and Mercati in MS Ba. We continue the translation nearly at the bottom of column 2 with Praeterea ad 1. 60 Parisiinum 1357...]

[V.2] In addition, his brothera contributed a fresh recension of Paris 1357 for Bks. 46-48, and Tischendorf one of Paris 1350 for Bk. 60; at times he adduced Vatican 2075 for Books 49-52. Zachariae (Leipzig 1846) published a supplement with a fuller edition of Books 15-18 from the Constantinople (now Berlin) MS. Thus in Books 10, 20-27, 30, 38-42, 49-52 we [VI.1] rely solely on the Fabrot and Reitz editions, but in the others apart from that we have collations that can be trusted very little.

There is an alphabetical synopsis equipped with scholia from about the middle of the $10^{\text {th }}$ century, derived from the complete Basilica ekloge kai sunopsis ton basilikon hexakonta biblion sun parapompais kata stoicheion ["Selection and synopsis of the 60 books of the Basilica, with line references"]. After Leunclavius (Basil 1575), it was edited by Zachariae, Ius Graeco-Romanum V. From the same time there is the [Greek] Ecloga of books 1-10, which formerly went, wrongly, under

1 That not even this book was intact was shown by Krueger, Zeitschr. f. Rechtsgesch. IX 193, Zachariae, Beitr. zur Kritik u. Restitution d. Basiliken. Mém. de l'acad. de St. Pétersbourg VII 23 (1877) n. 6.

${ }^{a}$ C.W. Heimbach 
the name of Theodorus. Heimbach brought out some parts of it, using the Meermann MS (cf. I p. XI).

Not of the same importance as the Basilica are two collections composed previously: ho procheiros nomos ["The Current Law"] (Prochiron) by the emperors Basil, Constantine and Leo between the years 870 and 878 (ed. by Zachariae, Heidelberg 1837), and epanagoge tou nomou ["Restoration of the Law"] (Epanogoge) by the emperors Basil, Leo, and Alexander between the years 879 and 886 (ed. by Zachariae, Collectio Librorum Iuris Graeco-Romani, Leipzig 1852). Each of these books has nearly the same contents, so that only the order differs; each is almost entirely compiled from Justinian's books, with only a very small number of the most recent laws being included; each makes use both of the Novels themselves (in a recension, however, which seems different from that of the Corpus of 168 Novels), and of Theodorus', and sometimes Athanasius' epitomes. In any places where these books depart independently from the wording of the Novels, variants are not always mentioned, but those alone which it seems must be derived from a tradition different from that of the Novels. Schoell did not pay attention to passages of the Novels cited in the scholia to the Epanagoge.

Both the Prochiron and the Epanagoge were augmented later. The Prochiron Auctum ["enlarged Prochiron"] was composed about the year 1300 (ed. Zachariae, IGR VI). It used epitomes, the Basilica, and the other sources, rather than the Novels themselves and is therefore rarely mentioned.

The Epanagoge Aucta (ed. Zachariae, JRR IV, $272 \mathrm{ff}$.) of the end of the $10^{\text {th }}$ century, added novels from Athanasius and the appendix of the Ecloga (p. VII).

The Epitome ekloge nomon twn en epitomw ektetheimenon kai eis $n$ titlous diermosmenon ["Selection of laws published in epitome and arranged under 50 titles"] was published in 920 by Constantine Porphyrogenitus. It drew very brief summaries of novels in part from the Prochiron, Athanasius, and Theodore, and in part from sources unknown to us. Titles 1-23 were edited by Zachariae, JGR II, 265 ff., 24-50 JGR VII (passages from the novels are listed at p. 211). Schoell rarely adduced these. 
The Collection of 168 Novels seems to have been adduced in the book entitled peri chronoon kai prothesmion apo rhopes heos hekaton eniautwn [“On periods and time-limits, from a moment to a century"], commonly known as hai rhopai ["The Moments"], (ed. Zachariae, Heidelberg, 1836). As now and then reference is made to numbers foreign to this collection, [VI.2] Zachariae suspected that it was a different collation that had been excerpted (72 ff. cf .265 f.), but that its numbers were altered later, with the steady increase in the authority of the Corpus of 168 Novels. However, as thus far only one MS is known, of the $14^{\text {th }}$ century, judgment ought to be withheld.

We have a complete Latin version, commonly called the Authenticum, of a different collection of novels. It contains 134 of Justinian's constitutions, which were all also in the Corpus of 168 Novels except 121 (Edict 8); many of these were translated from the Greek, but this collection contains 18 actual Latin constitutions of Justinian $(9,11,17,23,33-37,72-75,111,114,138,143)$. A rather obscure scholion before f. $51^{\mathrm{r}}$ of the Authenticum in the Vienna MS, collated by Schoell, and in the Nürenberg one, collated by Heimbach, says (I omit what is of less significance):a "There are one hundred (om. V, in a blank space) twenty-one constitutions, but an error was made previously between (within Nürnb.) $106 \& 108$ where 107 ought to have been... But because in my predecessor's MS (in codice om. V) there is the same mistake, and his transmission (-ones V) of it to us was in accordance with his own MS, I have decided (dixi MSS, corr. Zachariae) it is better not to emend the numbering. These (hee $V$, hec Nürnb.).) are those that were translated, which (tamen Nürnb.) or etiam ${ }^{b}$ ?) we only have in a Greek MS. Moreover, some Latin ones are mixed in with the Greek, and there are these which are only among the Greek. Not existing (etiam MSS, corr. Zach.) in the present MS are: 122 (120 V), 124 (0m. Nürnb.).), 125, 128, 130, 132.” This scholion has been discussed by Biener, $575 \mathrm{f}$. Heimbach, Prol. Auth. LXIII, CCCXVI; Zachariae, Sitzungsber. d. Berl. Ak. 1882, 1000

a What follows is also in italics in the text and appears to be quoting the Latin of the manuscript in question. The non-italicized parts within the italicized quotes appear to be Kroll's comments.

b Etiam gives a more intelligible sense ("which we also have in a Greek MS") but is less likely to have been corrupted into tantum. 
ff. Zachariae said that it did not relate to the Authenticum at all, but to Julian's Epitome, and says it was written in the year 555/6; Krüger, Gesch. d. Quellen., 357, 29 agreed. However, it is most likely that these words were written by some jurisconsult who compared the MS of the Authenticum with a collection of the 168 Novels which already then contained Latin constitutions. "My predecessor's MS" seems to mean a MS owned by his mentor, not of the Julianum, but of the Authenticum. These words are not appropriate to the actual MSS V and Nürnb., even if one should establish that the numbering has been corrupted, but could have come down to each of the two from a book that actually was as described. But to leave that aside, the Authenticum is a Latin version (aside from those few novels that were written in Latin from the outset) of a more or less chronologically arranged collection, from the Justinian era, similar to the Corpus of 168 Novels, made in the $6^{\text {th }}$ century itself; for although [VII.1] it bristles with extremely silly faults, it is not far from Justinian's style. Zachariae, l.c. 993, conjectured that it was the collection made shortly after the year 554, when, according to Justinian's directive (App. 7), the laws were to be sent over to Italy. But this conjecture is a false one, if only because the constitution on Vigilius' petition is missing, and because it does have Nov. 143, a law promulgated in 563 (cf. on p. 708, 18). Ninus Tamassia, professor at Padua, offered other opinions, not to be disregarded, in a dissertation called "Per la storia dell' Authentico"' (Venice 1898: Atti del R. Istituto Veneto, vol. ix, ser. VII). I owe the fact that I was able to examine this to the kindness of L. Seuffert of Monaco and of the author himself. This learned man, then, attempts, as I myself also had posited, to demonstrate, by arguments drawn from its style, that the translation was made in Justinian's time; and he also asserts it to have been created in Italy, a very difficult thing to prove by that kind of argument. It originated, he says, in the office of the praetorian prefect of Italy, in Ravenna, where, he posits, the Greek laws were brought shortly after 554 (cf. App. 7) and were turned into the Latin language by various officials; this is certainly attractive, but not definite. For what M. Conrat conjectures in his most useful book (Gesch. der Quellen u. Literatur des röm. Rechts. I Leipzig 1891 p. 132) also may be true, that it was translated in an office in Illyria. Against this, Th. Mommsen (Zeitsch. d. Sav. St. XXI, 
155 ) claimed it to be an $11^{\text {th }}$ century version rather than one of $6^{\text {th }}$ century origin, which opinion is worthy of disapproval for many reasons, pretty much those brought forward by Tamassia. This edition contains a new recension of the Authenticum, the sources for which I shall speak of below.

We know of a third collection, mainly from a Latin epitome of Julian ${ }^{1}$ the Anticensor, of Constantinople. This was made on the basis of a collection of 124 novels, encompassing Greek and Latin ones, after the year 555 (constitution 117 is dated $1^{\text {st }}$ June 555), in Justinian's reign; there is nothing in it that was not included in the Corpus of 168 Novels apart from chapter 29, which corresponds to Edict 3. The order of the first and last ones seems haphazard, but chapters 40-117 were placed in chronological order (not, however, too accurately), chapters 40-111 being in the same order as they stand in the Corpus of 168 Novels. Julian added very little of his own (cf. ch. 43); he omitted the inscriptions, prefaces, and epilogues; he seldom followed Justinian's wording closely (cf. chs. 111, 115), and for the most part abbreviated it; but he did always put subscriptions underneath, although the copyists quite often omitted them. Consequently, Julian is not of that much value in restoring the actual wording of the novels, [VII.2] but he is of correspondingly more for the subscriptions, especially since he has come down in very ancient MSS. Of these, those that are mentioned in this edition are:

Berolinensis (previously Rosnyanus, once Pithoeanus) lat. 269 in fol., $8^{\text {th }} 9^{\text {th }}$ centuries (Haenel, p. IV, for whom it is 4): contains all of Julian with the Appendix, about which I shall speak below. The subscriptions are often omitted; Schoell noted those that there are.

Parisinus lat. 4568 (formerly Ranconetus') in $4^{\circ}, 9^{\text {th }}$ century (Omont),

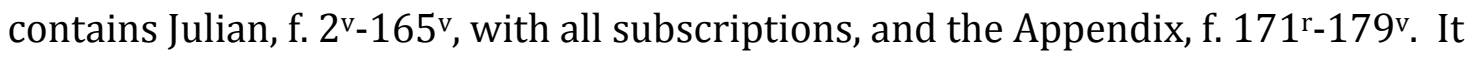
was collated by Haenel (for whom it is 2); and Girard, with the assistance of

\footnotetext{
1 Poems by "Julian the Lawyer, or the Anticensor" (Ioulianou scholasticou vel antikensoros) [it's not sure that either of these names refers to the famous lawyer Julianus] are extant in Anth. Pal. IX 481 [the Lawyer], XI 367-369 [the Anticensor].
} 
Mommsen, most generously collated Nov. 143 (on which Krumbacher had previously made some remarks) and App. 1 and 7.

Vindobonensis lat. 2160, $10^{\text {th }}-11^{\text {th }}$ centuries (Haenel, p. VI, for whom it is 5),

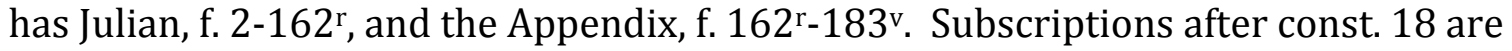
nearly all omitted; those included are given by Krueger, who also collated Nov. 143; Hartmann, at Mommsen's instance, collated Appendix 7.

Vercellensis bibl. capit., $10^{\text {th }}$ century (Haenel p. VII, for whom it is 6), supplies Julian and the Appendix; it preserves only a few subscriptions. G.E. Heimbach collated it.

Seldom adduced is Sangallensis 1395, $7^{\text {th }}$ century, which contains seven now greatly faded folios, chapters 346-362 with subscriptions (collated by Haenel) and Paris. lat. $4418,10^{\text {th }}$ century (collated by Haenel).

Julian's Appendix contains both laws drawn from the Authenticum (also summaries of some) and ones not known from any other source. Apart from the MSS we have just named, the following should be mentioned:

Mediolanensis, of the Trivulzian library, $9^{\text {th }}$ century (Haenel p. III, for whom it is 3a). Haenel received a variant version of App. 7 from the Conte di Vesme.

Coloniensis (previously Wallraffianus) X $8,12^{\text {th }}$ century (Klenze, Zeitscr. f. gesch. Rechtesw. VIII, 132) adduced by Schoell (who collated it himself) on 34 and 143.

Utinensis eccl. metrop., $10^{\text {th }}$ century (Haenel p. VIII, for whom it is 7). It also has several subscriptions and is the sole source for Appendix nos. 2, 3, 6 and 9. Collated by Haenel.

Here, then, is the order in which the Appendix occurs (I report only the facts relevant to the present edition; I put the summaries in brackets):

Utin.: (134), 34, (65), 114, 143, 138, (140), (121), Ap. 6, 9, 7, Nov. 140, Ap. 1-3

Paris.: 143, Ap. 7, Nov. 140, Ap. 1

Triv.: 143, Ap. 7, Nov. 140, Ap. 1

Berol.: (134), 34, (65), 114, 143, 138, (121), 134, 117, $1.2^{1}$

${ }^{1}$ These are the same as in Haenel's MS, with the exception of Nov. 117, c. 1.2, etc. 
[VIII.1] Vindob.: 341, 114, 143, (121), 134, 117, 1.2, Ap. 8

Vercell.: 34, (65), 114, 143, 138, (121)

Of the older editions two are worthy of mention: those of Miraeus (Lyon 1561), who mainly used Raconetus's MS (Iul.p), and of Pithoeus (Basel, 1576) who, as well as other books, also used an unknown one containing Appendix 2 and 3. This century, Julian was edited with a plentitude of subsidiary information by G. Haenel, Leipzig 1873.

In addition to these three collections, we detect several traces of others. The epitome ton meta ton kodika nearon ["Epitome of the Novels subsequent to the Code"] of the lawyer Athanasius of Emesa was made in Justinian's reign, from a collection of novels perhaps no different from the one that later became part of the Corpus of 168 Novels; included are, to be sure, all with the exception of 138, 139, $141,147,149-152,160,161,163-168 .^{2}$ Of those, 161, 163 and 164 are Tiberius's, and 166-168 are prefects'. There is an epitome of one novel that is neither included itself in the Corpus of 168 Novels, nor is there one similar to it: 20, 5. The material as a whole is arranged in 22 sections, with headings (e.g. the first is entitled [Greek] On bishops, clergy, monks and monasteries). The individual constitutions follow, each with heading, inscription, and subscription. The headings are often different from those that are in the Corpus of 168 Novels, but are quite often in agreement with those that Theodorus and the Authenticum offer. Notes are appended at the end of each section, drawn from Athanasius himself. An edition of Athanasius' epitome was made by Heimbach (Anekd. 1), generally using the incomplete MS Paris 1381 of the $11^{\text {th }}$ century.

This epitome was used by the compiler of the collection of Ecclesiastical Constitutions, as it is commonly called [Greek] (Law of emperor Justinian. Collection of constitutions stated in the Code, Digests and Novels, on bishops, clergy, monks, monasteries and religious houses; also on Jews and heretics). In the third chapter of

\footnotetext{
${ }^{1}$ Novels 34 (end) and 114 (beginning) have dropped out (cf. at 241 10, p. 533, 15); also the summary of Nov. 65.

${ }^{2}$ Supposing it were fact that Ath. 19, 1 relates to Ed. 3, then Nov. 21 would also be lacking; but I am sure that that passage refers to Nov. 21 (cf. note p. 760).
} 
this are contained the Athanasian epitomes of the 34 novels in the first three sections of Athanasius; in the notes to this chapter several of the following sections are cited; moreover, novels are also often mentioned in the notes to the first chapter. There is an edition based on Fabrot's $2^{\text {nd }}$ recension in Voell and Iustell Bibl. ${ }^{a}$ II 1223-1361 (hence sometimes mentioned as Ath. Fabroti); variant readings are brought by Pitra, Juris eccl. Graecorum hist. et mon. II 410 ff. Into [VIII.2] MS Monac. $380,13^{\text {th }}$ or $14^{\text {th }}$ centuries, f. 363, of this collection, Nov. 77 was inserted: it has been collated by Schoell.

Also wholly derived from Athanasius is the little book peri diaphoron anagnosmaton ["On variant readings"], which Heimbach edited, Anekd. I $185 \mathrm{ff}$.

Use of an epitome of the Novels similar to that of Julianus is betrayed by the Nomocanon of 14 Titles; the Epitome to the Prochiron, altered; and the Appendix to the Ecloga.

The Nomocanon of 14 Titles came to us in the form that some person gave it in 883 (whose preface is in Pitra II 448 f.; they used, falsely, to say that it was Photius). Its most ancient version seems to have been of the $6^{\text {th }}$ century; the second was made between the years $612-692$ by the person who also wrote the book peri enantiophanon ["On Apparent Contradictions"]. His additions are rarely the words of the novels themselves (120, c. 10), but generally summaries of novels, drawn both from the Collection of Ecclesiastical Constitutions, and from a lost epitome similar to Julian's. ${ }^{1}$ In a commentary of 1090, Theodorus Bestes (whose Preface is in Pitra p. 449), added several passages from the novels from the Basilica; and Theodorus Balsamon added a few in a commentary from the end of the $12^{\text {th }}$ century. In addition, copyists sometimes wrote in things that seemed to them to be useful (cf. on N. 12, 13, c. 9 and 17, 131, c. 8). Pitra (II 789-1140 l.c. 433 ff.) edited the Nomocanon after Voell and Iustell. Two MSS especially noteworthy for their collections supplemented by Theodorus's commentary are: Dublinensis, coll. Trin.

${ }^{a}$ G. Voell \& H. Iustell, Bibliotheca Iuris Canonici Veteris, 2 vols. Paris 1661.

${ }^{1}$ Biener 202 ff.; Krueger, Z. f. Rechtsg. IX (1870) 185 ff.; Zachariae, “Die griech. Nomokanones," Mém. de l'acad. de St. P. VII, 223 (1877) n. 7; and: “Über d. Verf. u. d. Quellen d. pseudo-photian. Nomokanon in XIV Titeln" Ibid. VII, 32 (1855) n. 16. 
$494,12^{\text {th }}$ century, and Monac. $122,12^{\text {th }}$ century, discussed, and the additions edited, by Pitra I 660, II 441 ff., read by Schoell.

The Epitome to the Prochiron, altered, is in the magnificent $11^{\text {th }}$ century MS Bodleianus 3399 (Selden 10: Coxe 590), and in Marcianus 579. Inserted in that are fragments of the epitome of the Novels that was also used by the "Enantiophanist," which Zachariae (Anekd. 208 ff.) edited from MS Bodl.

A $9^{\text {th }}$ century appendix was added to the Ecloga of Leo and Constantine of 740; it generally drew novel summaries from the epitome, adduced by the "Enantiophanist," but sometimes excerpted actual novels. Zachariae (Anekdot. 184 ff.) edited this from MS Paris. 1384, $12^{\text {th }}$ century. In turn, the Ecloga to the Prochiron, altered (ed. Zachariae, JGR IV, 49 ff.), ${ }^{2}$ drew summaries of the novels from this, and additionally from Athanasius, Theodorus and an unknown source as well.

[IX.1] It remains for me to set out the other authors who have used the Novels.

What is commonly called The Collection of 25 Chapters [Greek] (Constitutions of civil laws from the Novels of Emperor Justinian, supporting and confirming the ecclesiastical canons of the holy Fathers), compiled in the $6^{\text {th }}$ century, provides, after laws drawn from the Code, Novels 137, 138, 120, and 131, c. 13. It was edited by Heimbach (Anekd. II, 145 ff.) from the MS Monacensis 380. For the last part, containing the novels, he also made use of the Paris MSS 1324, 1326, and 1334. Variant readings, mainly from MS Palat. 376 , of the $11^{\text {th }}$ century, were produced by Pitra II $407 \mathrm{ff}$., cf $373 \mathrm{f}$. Schoell used his own collations of Monac. 380 for Novel 120, also Paris. $1326,11^{\text {th }}$ century, Paris. 1334, $10^{\text {th }}$ century, and Laur. 10, $10,11^{\text {th }}$ century; and Krueger's for all the novels.

A Collection of 87 Chapters was created by Johannes, a lawyer of Antioch, around the year 550 (he was Patriarch of Constantinople 565-578), from novels that were then still dispersed [Greek] (Transcribed from variously-dispersed Novel constitutions promulgated by Justinian, of divine destiny, after the Code). It provides Novels that are pertinent to church law, partly whole (in which case they are prefaced with headings and inscriptions), and partly summarized. This book, as

2 I have no knowledge of the Epitome Marciana (MS Marc. 172), said by Zachariae, Mém. VII 32 p. 6, to have been used by the epitome of the Enantiophanist. 
well as Athanasius' epitome, was used by the person who made the Nomocanon of 50 Titles, to which was added an Appendix of Ecclesiastical Constitutions, compiled from a Collection of 87 Chapters, and containing the chapters from this collection that had not been included in the Nomocanon itself. ${ }^{1}$ - Heimbach edited the Collection of 87 Chapters, Anekd. II $208 \mathrm{ff}$;; and Pitra II $385 \mathrm{ff}$. the Nomocanon of 50 Titles, from Voell and Iustell II 603 ff., using, with other MSS, Vat. 843, 9 $9^{\text {th }}$ century (cf. Pitra 416 ff.).

It is uncertain whence was derived the selection of the MS Ambrosianus ( $p$. X) which was made after Heraclius, as Zachariae concluded (Zeitschr. d. Sav. St. XIII, 8) from the passage at p. 21, lines 8-10 (cf. Coll. I, Nov. 22) and from the mention of subjects on p. 663, line 23, novel summaries were taken from it in the Private Enlarged Ecloga of the $9^{\text {th }}$ century (ed. by Zachariae, JGR IV).

The Collection of 13 Edicts of Justinian comes down only in the Codex Marcianus. One would suppose it to be a supplement consisting of some collection made during Justinian's reign, e.g. that used by Athanasius. ${ }^{2}$

The earliest [IX.2] is the second, dated between the years 531-535, the last is the eleventh, dated 559. The first and sixth are repeated in the Corpus of 168 Novels; Julian's constitution 29 shows knowledge of the third; the fourth is extant in the corpus of the Novels only in its Latin form (111); the eighth's version is 122 in

\footnotetext{
${ }^{1}$ Biener explained the matter, 194 ff., 584 (cf. Heimbach II p. LIV, Zachariae, Mém. de l'Acad. VII, 23, and Zeitschr. d. Savignystiftung, röm. Abt. VIII 236 ff.).

${ }^{2}$ Biener 53 and Zachariae, Gesch. 7, wish it to be a supplement to the Corpus of 168 Novels, excerpted from a more ancient collection, which Zachariae, without sufficient cause, posited as having been made in Alexandria; but Edicts 1 and 6 are also extant in this corpus. Zachariae (Zeitschr. d. Sav. St. XIII, 44 ff., XV, 366 ff.) supposes himself to detect traces of that fuller collection in a note on Nov. 1 (p. 10, line 6) and in the heading placed above Nov. 112, instead of in its right place at the head of Ed. 5 (=Nov. 111) [Greek]: "On litigiosa; and on cautio plaintiffs must lodge before the summons to defendants" - but this was nothing but a copyist's error. He ought not to have concluded (XV 368) from the gloss (p. 521, line 20) that Edict 5 had been translated from its Latin form (Nov. CXI). Unless the supplements proposed by him (l.c. p. 50 ff.) in the last edict, on the ground that he had persuaded himself that a papyrus archetype of this edict and its individual leaves had been mutilated at the foot, were recommended on their own merits, I have not mentioned them.
} 
the Authenticum.; there is an epitome of the ninth in an anonymous Bodleian MS. Beyond this no trace of them appears anywhere.

Of the collections we have enumerated, two are offered in this edition: the Corpus of 168 Novels and the Authenticum, with the Appendix of 13 Edicts and, in addition, Justinian's constitutions that have come down outside the Code. ${ }^{a}$

Among the resources for a recension of the Corpus of 168 Novels, first place is easily held by the Greek Codex Marcianus 179, which had once been Bessarion's, parchment, in folio, of 415 leaves, damaged at the end, written in inelegant lines, with numerous abbreviations, by a $13^{\text {th }}$ century copyist. ${ }^{1}$ Another hand of the same age only corrected blemishes. The book contains these:

On a prefixed leaf there is a [Greek] Table of the Novels of the Lord Leo, incomplete, as it leaves off at [Greek] Novel 25, Payment in potestate, and repayment, of dowry. The writing is all in a hand of the $15^{\text {th }}$ century.

On the verso of this leaf, we see written: [Greek text omitted]

[X.1] Thereafter in the hand of Bessarion: [Here Kroll continues with a detailed analysis of this MS, Marcianus 179; we have omitted it as being beyond the interest of all but a few readers, who are likely to be able to read Kroll's description for themselves. We continue translating at the top of page XI with Codicem contulit Schoell...]

[XI.1] Schoell collated the MS; where Zachariae had had different readings, he usually took pains to inspect doubtful places anew. Readings have been noted carefully, apart from the most trivial ones, with which they commonly clog up the

\footnotetext{
a In this edition, the edicts and extra constitutions follow the text of the Authenticum and Corpus of 168 Novels in an appendix titled Corporis CLXVIII Novellarum Appendices- "Appendices to the Corpus of 168 Novels" The edicts are referred to as Iustiniani XIII Edicta Quae Vocantur-"The So-Called 13 Edicts of Justinian," and the others are labeled Appendix Constitutionum Dispersarum- "Appendix of Dispersed Constitutions."

1 There are descriptions of it in Zanetti-Bongiovanni 103, Morelli Bibl. Ms. I 103, Bluhme in Biener $617 \mathrm{ff}$., and Zachariae ed. Nov. I, p. VII ff. An illustration is given by Wattenbach-van Velsen, tab. L. I think it useful to describe the MS in minute detail. [We have omitted most of that detail here as being of little interest to most readers.]
} 
apparatus uselessly: mistakes corrected by the first hand, in accentuation, $v$ "paragogicum," o from $\omega, \eta$ from $\mathrm{l}$, and suchlike.

Far inferior to the Codex Marcianus is the Laurentian (formerly Bibl. S. Marc., Florence) plut. LXXX 4, paper, in folio, 194 leaves, mutilated at the end and at the beginning. ${ }^{1}$ It was written in the $14^{\text {th }}$ century, with lines of uneven length, by two copyists...[Extensive details concerning the MS follow and have been omitted.] [XI.2] [We continue half-way down column 2, with Codicem L. contulit Schoell...] Schoell collated MS L; for I [a copy of L, Bologna public library B 4. 67] he used Maier's Tübingen notes and a collation by Krueger.

I describe here, only for convenience, a MS Ambrosianus L. 49 sup., that contains several novels certainly not drawn from the Corpus of 168 Novels. It is of vellum in a quarto of 227 leaves...[Again, details, which we omit, follow to halfway down p. [XII.1], where the text begins Nuper innotuit...]

There recently came to light a MS of novels older than any other, Vallicellianus 95 (formerly F 47) of the $11^{\text {th }}$ century, which E. Martini reproduced in the Catalog of Greek Mss Existing in Italian Libraries II, 162 pp. In fol. 281v sqq., it contains Novels 137, 3, 77, 132 and 133, for which the numbers are inserted in the margin 87, 90?, 93. My friend Nic. Festa had collated a portion of this (the greater part of Novel 3) for my use; but then G. Bortolucci of Modena, in Rendiconti della Accademia dei Lincei, Classe di scienze morali, vol. CVII (1908) listed all the variant readings. And since I had already recognized, from the gleanings of Festa, that the ancient MS (which Bortolucci wished to assign to the $10^{\text {th }}$ century rather than the $11^{\text {th }}$ ) did not offer anything of a kind likely to be of value, I could not bring myself to list the variant readings of all five novels, but I enumerate here only those of Nov. 3: [XII.2][XIII.1][XIII.2][On these pages there is a more than two-column list of the variant readings, which we have omitted. We continue at Haec opinor ad indolem...]

These, I think, will suffice to grasp the character of the MS.

${ }^{1}$ Reproduced by Bandini III 174, Biener 557 ff., and Zachariae I p. VI f. 
The Greek Novels were first edited by Haloander (Nürnb. 1531) who used only the Bologna copy; ${ }^{1}$ thus he edited a complete text of only 122 Greek novels, improving some, and rashly corrupting more; his final achievement cannot be established without an accurate knowledge of MS l (cf. Heimbach, Zeitschr. f. gesch. Rechtsw. VIII $324 \mathrm{ff}$.). In the Basel edition of 1541 some passages seem to have been corrected with the aid of MS M (Biener 354); twenty-five emendations of passages were published in an appendix, and in the 1542 Paris edition these were transferred into the text. It was the Scotsman, Henry Scrimger, who, in Augsburg in 1556, first published the contents of the Marcianus, whether using the Marcianus itself, or-as is much more likely, since Heimbach's discussion l.c. $330 \mathrm{ff}$ - - a copy of it, MS Palatinus 387, carefully prepared, at least as far as can now be judged. He corrected a few places, rather slight ones, using sometimes the vulgate version, sometimes Haloander's edition, sometimes the application of his own judgment. After these men, Agylaeus emended a number of places in a Latin version of the Novels (Basel 1561), in part tacitly, in part adding brief notes. Contius mixed Haloander and Scrimger's work in his edition (Lyon 1571), which one could rightly call the basis of the received text, because subsequent editors contributed little, whether to emendation, or to recension: some corrections were made by Hombergk, in his Latin version (Marburg 1717, does not include the Edicts); Spangenberg more (Göttingen 1797), who also had Vigl Zwichem's 1553 excerpts from M, and edited the scholia mainly from those. ${ }^{2}$ Beck, in his Leipzig editions (of 1834 and 1837) contributed practically nothing remedial to the Greek text, and little more did Osenbrüggen (Leipzig 1840).

At long last, it was Zachariae who finally demolished the vulgate text in his Teubner edition published in 1881 (he added an appendix [XIV.1] in 1884 and re-

${ }^{1}$ Biener reviews all editions of the Novels and the Authenticum, pp. $317 \mathrm{ff}$.

2 Of the perhaps three Meermann MSS in Spangenberg's possession (Biener $555 \mathrm{f}$., 572 f.), the only one I have hunted down is Cod. Meerm. 178 (=Phillipps. 1499: L. Cohn, Verz. D. Meermannhss. 39). It has (f. 11v) the Nomocanon of 50 Titles (f. $156^{r}$ ), the Coll. of 87 Chapters, (f. 179r), the Collection of 25 Chapters (f. 209r), the Novels of Leo (f. 301 r), the novels not in Haloander's edition (f. 363), the edicts of Justinian, Justin and Tiberius. It appears therefore to be Meerm. III. 
edited the law on the diocese of Egypt in 1891). That it is worthy of so great a man scarcely needs saying. He was first to collate MS M in its entirety; he examined L and A now and then; he applied the other witnesses to the Novels for the purpose of restoring the original text; yet his achievement was due no less to his sagacity, and acuity of judgment, than to his diligent use of those resources. The fact that he also changed the order of the constitutions to a chronological arrangement (omitting those of Justin and Tiberius, and the prefectorial directives) ${ }^{1}$ is indeed not a convenience, and is to be deplored, in view of the uncertain dating of many of them.

I come to the resources for editing the Authenticum.

These, then, are the MSS that Schoell chose from the huge number that exist (Heimbach knew of 129):

Vindob. Lat. 2130 (iur. civ. 19 cf. Heimbach LXIII ff.) parchment in folio of 233 leaves. The careful script is of the $13^{\text {th }}$ or $14^{\text {th }}$ centuries, and its contents are these:

f. 1-50 Institutes

f. 51 ${ }^{\mathrm{r}}-191^{\mathrm{r}}$ Authenticum (remains of leaf 191, and leaf 192 are blank)

f. 193r-233 Code, books X-XII (Krueger's J). This part was written by the hand that made corrections in the Authenticum ( $\left.\mathrm{V}^{2}\right)$.

The order of the novels, which in most of the MSS is extraordinarily disturbed (because they at first ejected the unglossed ones; later they included them again, but often not in the original place, but rather added an appendix of stray constitutions) ${ }^{2}$, is nearly intact in this MS: $1-10,12,14-20,22-103,105,104,106-$ $119,133,120-130,132-11,13,21,66,86,134.131$ is therefore omitted, 66 and 86 are placed twice. Both inscriptions and subscriptions customarily are given; here and there Greek numbers are added to the Latin ones. A note of the collation and title is generally added; there are glosses belonging to pre-Accursian time, perhaps

${ }^{1}$ The former he published in JGR III, the latter in Anekd. $249 \mathrm{ff}$.

${ }^{2}$ After the Authenticum was found in the time of Irnerius, they selected from the 134 Novels 97 that they annotated with scholia; these they arranged in new collations (Heimbach's survey: Proll. DCCX ff.). Using the careful work of others, Accursius composed his own gloss in the year 1220; those glossed are the same as those in the collations, except that 105 (Arabic numbers are of the Authenticum) is collation VII 6, but lacks the gloss; 40 does have a gloss, but it is absent from the collation. 
added by the first hand, and Accursian ones added later, but apparently in the $14^{\text {th }}$ century, with very few more recent ones. Another hand of the same period supplemented in black ink, more often than emended; a third, much newer (there may perhaps be two) in light ink made emendations from a second MS. This MS, far superior to all others, was collated by Schoell.

The Berolinensis [Berlin Codex] (previously Rosnyanus 2394, formerly Pithoeanus; Krit. Jahrb. I, 189 Heimbach LXIII ff.) Lat. fol. 271, parchment, of 162 leaves. It contains:

[XIV.2] f. 1-78: the Authenticum, written in the $13^{\text {th }}$ century. The first quaternion of the writing was written in another hand of the same age; ${ }^{1}$ the same one at the end of f. $98^{\mathrm{v}}$ added Nov. 52.

f. 79-86: three components of MS T, removed to this place. The first includes Novel 8 from c. 13 aut aliquos tales (p. 76, 39), 9, 10 up to neque impetra (p. 93, 12); the second (f. 82); Nov. 72 pr. from turam esse nostrae (p. 355, 24) and 73 up to si uero alter (p. 351, 27); and the third (f. 83-86), Nov. 3 from toga dicimus (p. 497, 27) $37,38,39,40$ up to quas liberi (p. 246, 25) 44 from the words lege confirmantem (p. $271,3)$, Nov. 49.

f. 87-162; part of a third MS, in which are included: f. 87-91 an appendix of Novels, written in the $14^{\text {th }}$ century, embracing these constitutions: 123 from habet fidutiam (p. 712, 12) 124, 70, 66, 60, 65, 67, 21.-f. 91-110; several chapters of Julian (cf. Haenel XVI).-f. 111-154: Rogeri's summary of the Code, damaged.-f. 155-162; fragment of a little work about canon law.

Of f. 1-78 there were these points to be noted. The order of the novels is this: $1-10,12,14-20,22,23,34-36,41,45,46-48,50,51,53-59,61,62,68,69,71-86$, 88100, 102-104, 106-115, 117, 119, 120, 126-130, 132.-11, 13, 21, 66, 86, 134, 52 (added by $\mathrm{R}^{2}$ ). It is by no means rare that a scholiast has noted which constitutions were omitted. A rubricator colored red the initial letters, the number of the collation in the upper left-hand margin, and of the titles on the right, in the outer margin the inscriptions of the chapters, and in the text the sign $\varsigma$ to denote

${ }^{1}$ Heimbach speaks falsely of the components of the other MS; f. 8 in error was introduced between 1 and 3 , as they are now numbered. 
paragraphs. A second hand often corrected errors of the first, and added N. 52Collated by Schoell.

Monacensis Lat. 3509 (iur. civ. 10, formerly August. civ. 9), parchment, in folio, of 302 leaves, $13^{\text {th }}$ century (Heimbach LVI ff.). The Institutes are followed by the Authenticum f. 45-199, whose principal part extends through f. 173v two appendices were added, one of the two f. 174-177 by a second hand of about the same period, f. 178-199 perhaps from the same second hand. The gaps contained are by no means scanty, because some of these leaves were pulled out and transferred to R; f. $64^{\mathrm{v}}$ ceases at aut armatos p. 76, 39; f. 65r begins at bit petita p. 93, 12; f. $101^{\mathrm{v}}$ ends at neque ecclesiam Nov. 69 c. 1 p. $344,26,102^{\mathrm{r}}$ begins at quibus modis Nov. 74 , p. 370,7 , f. $198^{\text {r }}$ begins at curialibus Nov. 40 c. 4 p. 250 , 32. Thus one leaf was altogether lost.

The order is about the same as in R: 1-10, 12, 14-20, 22, 23, 34-36, 41, 45-48, 50, 51, [XV.1] 53-59, 61, 62, 68, 69, etc. (It lacks an accurate description.) Leaves 174-177 encompass Novs. 128, 52, f. 178-199 Novs. 101 (a very recent hand added the note: alii libri non habent istam constitutionem de donationibus curialium nec sequentes ["other MSS do not have this constitution on gifts by curials, nor the following ones"]) 105 (exists twice), 116 (exists twice), 118, 122-125, 131 (exists twice), 24-33, [37-39], 40, 42-44 [49].

Schoell first excerpted selected readings of Codex T [Codex Monacensis Lat. 3509, noted above], first known from Heimbach; later (from Nov. LXXIX, p. 388) he himself collated it no less diligently than V [Codex Vindob. Lat. iur. civ. 19, $13^{\text {th }}-14^{\text {th }}$ centuries] and R [Codex Berolin. 271, 13 ${ }^{\text {th }}$ century].

Of the other manuscripts, these were sometimes turned to: Orielensis, Oxford, 22 (A II 7), parchment $13^{\text {th }}$ century (Heimbach XVII, Coxe 7, Krueger praef. Cod. VIII). Schoell used the collation of subscriptions to Nov. 17, and of the few extant, prepared by Krueger.

Escorialensis, bibliotheca alta I S 9, parchment, $13^{\text {th }}$ century (Heimbach LIII), from which Dionysius Gonzales reproduced the inscriptions and subscriptions. 
Bambergensis D II, 11 parchment, in folio, 14th century, of 217 leaves (it is Jaeckius's $814+824+833$. (Heimbach LXI ss. confused this MS with the following one). It contains:

f. 1-49v Justinian's Institutes

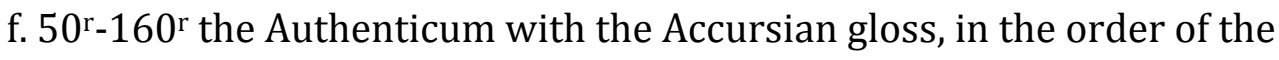
customary nine collations, except that the order in the ninth group is: $1-3,5,6,14$, $15,7-13$, 4. At the end, Novel 52 is added, as in R. Subscriptions are added to these Novels: 8, 53-59, 61, 68, 71-77, 79-85, 88, 134. Schoell at first excerpted variants from Heimbach's apparatus; afterwards (from Nov. 8, p. 390, 13) he used his own collation. Those of the earlier novels that are erroneously reported from Heimbach we have corrected in the index of subscriptions and addenda. ${ }^{\mathrm{a}}$

f. $161^{r}-216^{r}$ Code books X-XII, with the gloss. In empty space on f. $161^{\text {rv }}$ and $217^{\mathrm{r}}$ a recent hand wrote indices and addenda.

Bambergensis D I 1, parchment, in folio, of the $14^{\text {th }}$ century, 266 pp. (Jaeck 826), contains these:

p. 2, 3: table of treatises;

p. 5-164: Authenticum, according to the nine groups, except that IX 4 is missing. All the unglossed novels are missing. These have subscriptions subjoined: 1, 4-10, 12, 14-20, 22, (23), 41, 45, 47, 48, 89, 90, 92, 93-95. Here, too, from Novel 89 , p. 445, 5, Schoell used his own collation.

p. 165-264: Books X-XII of the Code, written in a second contemporary hand.

p. 265, 266: indexes and tables.

As to the subscriptions, variant readings are mainly adduced from these books, following Heimbach's apparatus:

Vindob., Lat., iur. civ. 4, formerly Ambrocensis, parchment, $13^{\text {th }}$ century (Heimbach LXIX).

[XV.2] Vindob. Eugenii 157, parchment, 14th century (Heimbach LXX).

Claustro-Neoburgensis 62, parchment, $13^{\text {th }}$ century (Heimbach LXX).

a I.e. C.I.C. III pp. 806-810. 
Parisinus Lat. 4429 , parchment, $13^{\text {th }}$ or $14^{\text {th }}$ century (Heimbach XLIII) showing very few subscriptions.

Pistoriensis bibl. capit. 103 (formerly E 4, 2), parchment, in folio, of 74 leaves, end of the $12^{\text {th }}$ century. The writing is in dual columns; the Anteaccursian gloss is present, generally with the Accursian written above it. Novels 11, 13, 21, 66 are placed between 14 and 15, 40 is missing; stray ones are 24, 31, 32, 37, 43, 44, 49, 52, $60,63-65,70,87,118,123$. Subscriptions are added to 8 (p. 80, 10, 88, 41) 121 (but cf. p. 772, 1), 123-125, 134; Krueger has reproduced these. There is a most diligent collation of Nov. 121 by Lud. Chiapelli, jurisconsult of Pisa, with the assistance of Buonamicius and Pulleus, professors at Pisa.

Monacensis 9359 (formerly Frisingensis), of the $14^{\text {th }}$ century, collated by Schoell for Nov. 116.

On any others to which reference has been made, you will find the requisite notes in the corresponding place.

The editio princeps was produced in Rome in 1476; both this and its successors, the great mass of which is not worthy of being reproduced, ${ }^{1}$ have almost exclusively the glossed ones. Of great moment are the editions of Contius, of which the first was produced in Paris in 1559 (from this stem that of Lyon in 1562, and its successors), and the second at Lyon in 1571. In the former, therefore, he added a new tenth collation, embracing 63 complete novels, clearly amassed by himself. Of these he drew only one (11) from MSS of the Authenticum, two (37 and 64) from Julian's Epitome, one (43) from Isidore's Canons; he printed the greatest part (47 whole ones and 8 summaries) not from the version of the Authenticum, but from that of Haloander, and three whole ones and one summary from his own; 25 of these were not in s [the Authenticum]. He reproduced the words of the Authenticum from the Paris 1511 edition, whose flaws he repeated; he himself in several places interpolated parallel text from a Greek copy. The later edition surpasses it to some extent; in it he provided the received text of the nine collations (there are 96 constitutions; for 126 is omitted, its place being taken by Haloander's version) and

${ }^{1}$ Cf. Biener 322 ff. Heimbach DLXXXIX ff. 
Novel 11 of the received version; of 12 constitutions $(13,21,40,52,60,101,122$, 118, 131, 123-125), he gave a version from MSS of the Authenticum, Novel 43 from the Acta Conciliorum, Novel 138 from Julian's appendix, six of Julian's epitomes, forty taken over from others, eight from himself; as for the ordering, however, he followed that of the Corpus of the 168 Novels. Thus all traces of both the form and the order of the true Authenticum were destroyed. Moreover he too interpolated the text from Haloander's version and from a Greek copy, with the greatest of license; [XVI.1] you will learn more on this subject from Heimbach's Prolegomena DCIX ff. and from his notes, since in this edition it did not seem necessary to include everything of the kind. ${ }^{1}$

Later editions went back to that of Contius; some gain was made from Pithoeus' collation (1573) and from Julianus (1576), in which he edited the old version of Novels 37-39, and 67. Beck (Leipzig 1836 and 1837) was the first to change the received order, by restoring the original, and he improved the text by inserting Novels 49, 63-65, 67 and 70, restoring the original, which Savigny and Biener had edited from $V$, and by suggesting emendations, often successfully. Beck was followed by Osenbrüggen (Leipz. 1840, etc.), who realized the corrupt state of the received version and worked to restore the original form of the text by inspection of old editions and from Nov. 22, of the Hamburg MS; he did not for all that make much progress (cf. Heimbach, Krit. Jahrb. II 792 ff.).

Therefore it was more or less Contius' text that was taken up by G.E. Heimbach, who created the first critical edition (2 vols., Leipz. 1846-1851). He who has devoted so much work to this matter is worthy of highest praise, although there was much wrong with his handling of it. He completely annulled Contius' authority, and from the vast number of MSS, he chose just a few leading ones which he wanted to be the basis of his recension; and the fact that he did not collate them accurately, and there is almost not a page in which he did not make a mistake in his report of a reading, is something more forgivable [XVI.2] in someone of that epoch than if

${ }^{1}$ It is not known which MSS he used, nor would it be of much importance to know, but for the fact that they provide some subscriptions not to be disregarded-if he can be trusted. 
anyone nowadays made such errors. He did not provide that much in the way of emendation.

Therefore, the plan of this edition is to restore both the Greek Novels and the Authenticum to their pristine form. In both tasks, extreme difficulties stand in the way; in the one, you often do not know whether it is Justinian's own words that you are emending, or those of the redactor of some summary, or of a more recent interpolator; in the other, it is often of the greatest difficulty to judge what the extremely silly man who translated it saw written in his copy of the Greek text, and what he understood by it. In the one, Schoell mostly followed the Codex Marcianus; in the other, he behaved with the utmost caution, mentioning even the most attractive conjectures only in the apparatus. The readings of MSS and of other sources are noted diligently, apart from the slightest errors, but of the conjectures of learned men, only those recommended by some plausibility.

The Latin translation has been wholly revised, in which Krueger has rendered great service; indexes have been added, as being commended by their inherent usefulness; in the Addenda and Index, more detailed mention has been made of the readings of the Bamberg MSS, as I said above, than in the notes to the text itself. It remains therefore to render most grateful thanks, in both Schoell's name and my own, to all of those who have earned them for this edition; above all to P. Krueger, T. Mommsen, Ed. Zachariae von Lingenthal, a man of most distinguished memory, besides my friend F. Skutsch, who in addition to Krueger and Mommsen assisted me in correcting the proofs.

Bratislava, 17th Nov. 1894.

I re-read and corrected what was necessary, and made additions, a second time at Bratislava, 27 ${ }^{\text {th }}$ March 1899, a third time at Greifswald, 23 ${ }^{\text {rd }}$ Sept. 1903, and a fourth time at Münster in Westphalia, 18 $8^{\text {th }}$ Dec. 1911.

Wilhelm Kroll 
